and settler women's healing work. Accessible and concise, this book is well suited for undergraduate students and non-scholars interested in broadening their perspectives of colonial history in Canada.

Venetia Boehmer-Plotz

Brock University

\title{
Benjamin Isitt, From Victoria to Vladivostok: Canada's Siberian Expedition, 1917-19 (Vancouver: UBC Press, 2010).
}

As Benjamin Isitt notes at the beginning of From Victoria to Vladivostok: Canada's Siberian Expedition, 1917-19, Canada's Siberian Expeditionary Force has traditionally been little more than a footnote in the history of the Great War (4). While Isitt is by no means the first historian to write about the expedition, he is the first to examine the ill-fated military intervention within the larger context of class relations in Canada, expansionist capitalism, and the labour revolt and its suppression. The result is a wide-ranging work that demonstrates the new insights that can be gleaned from old topics when the sometimes myopic fields of military and social history converge.

The Canadian Expeditionary Force Siberia (CEFS) was a Canadian led international military force mobilized in the summer of 1918 in response to the Russian Revolution of the previous November. Militarily it was a non-event: although 4,200 Canadian troops were dispatched to Siberia, only once (and briefly and without incident) did they come in contact with the Bolshevik forces they were sent to suppress. Perhaps for that reason, it has been somewhat neglected, generating only a few memoirs and military or political historical studies without much interest from the mainstream historical community.

Isitt uses the CEFS to call for a new dialogue between military and social historians as well as the importance of transnational history or, at the very least, the larger international context. (170) In casting the expedition as a Canadian attempt to simultaneously export western Capitalism while suppressing growing labour radicalism at home, Isitt calls into question the conventional nation-building narrative of the Great War. "From Victoria to Valdivostok," he argues, "the Canadian government had engaged in a battle against labour radicalism...the seething tensions and ambitions surrounding the Siberian Expedition-among Anglophone and francophone workers and farmers, Siberian peasants and partisans, White Russian soldiers and motley foreign troops, and Canadian financiers and the state-exposed the class basis of Canadian foreign policy. Canada lost in Siberia, its first foray as a world power, and then quietly ignored this history." (171) It is an argument which is supported by in-depth primary research into the contemporary newspaper and periodical 
literature as well as official archival sources such as court martial files and lowlevel military records which are underutilized by social historians. Overall, the book makes a convincing case that the military expedition is important to understanding Canadian responses to war on the home front by placing the experience of soldiers and military decision-making within a framework defined by classpolitics. At the same time, it reminds military historians that soldiers play a dual role as workers and combatants—sometimes unwillingly—and that military events require a larger social context.

The book itself is divided into eight chapters in two parts: "Canada's Road to Siberia" and "To Vladivostok and Back." In this reviewer's opinion, the first part of the book should be required reading for those doing labour or working-class history and war and society. Isitt is at his best here as he examines the capitalist imperative at home for intervention as well as the responses of working-class soldiers, most of whom were conscripts and unwilling to fight in Siberia against a worker's revolt—some, he contends, even mutinied (this chapter is, at least in part, based on the author's Canadian Historical Review article). The second part focuses on the many challenges facing the CEFS's military commanders and the experiences of soldiers lost in a strange land without direction or unity of purpose. While the analysis of the second part is not as even, he demonstrates that as commercial prospects dwindled and radicalism continued to spread at home, the impetus for the mission faded, resulting in the recall of the force in the spring of 1919.

Perhaps Victoria to Vladivostok's greatest strength is that it points towards several avenues of new research. As with the works of Robert Rutherdale and Amy Shaw, this book demonstrates that we still have much to learn about the war's social history in Canada, which challenges the dominant nationalistic, military/political narrative of events. Isitt's book suggests that working-class discontent during the war was far more pervasive than previously thought. It calls for a new interpretation of Canadian foreign policy and its furtherance of a home-grown, expansionist Canadian brand of capitalism. By the same token, one is left wondering how many other mutinies and acts of civil disobedience by Canadian soldiers might be uncovered if historians were to examine soldiers' agency and the class politics of obedience to military authority.

On the whole, Victoria to Vladivostok is a well-researched book that effectively bridges the gap between social and military history, two fields which rarely talk to one another in Canada but should do so more often.

Mark Osborne Humphries Mount Royal University 